\title{
VARIKOZINĖS VENOS: DIAGNOSTIKA IR GYDYMAS
}

\author{
Jokūbas Vitkus, Ignas Floreskul, Dainius Misevičius \\ Lietuvos sveikatos moksly universitetas, Medicinos akademija, Medicinos fakultetas
}

\author{
Raktažodžiai: varikozinės venos, storosios žarnos vėžys, \\ diagnostika, gydymas.
}

\begin{abstract}
Santrauka
Varikozinès venos yra dažnai užčiuopiamos išsiplètusios poodinès venos, su atbuline kraujo tèkme. Dažniausiai randamos kojose. Matomos kojose, dažnai besimptomès venos, stebimos kas trečiam populiacijoje. Tyrimo tikslas - išnagrinèti dažniausiai taikomus venų varikozès diagnostikos ir gydymo metodus. Atlikta mokslinès literatūros apžvalga ir analizè. Tyrimo rezultatai parodè, kad dažniausi patologijos rizikos veiksniai yra moteriškoji lytis, vyresnis amžius, rasè, šeiminè anamnezè, něštumas, ilgas stovejjimas, nutukimas, kraujagyslinès malformacijos ir hormonų terapija. Simptomai specifiški - edema, išsišokusios ir išsipūtusios varikozinès venos, skausmas kojose fizinio krūvio metu, odos cianozè, raudonis, hiperpigmentacija, lipodermatosklerozè, opos, gali būti stebima apskrita balkšva, nevaskuliarizuota, atrofinės odos zona, vadinama blyškioji atrofija (Atrophie blanche).

Išvados. Auksinis diagnostikos standartas - klinikinis vaizdas kartu su duplex ultragarsiniu tyrimu. Simptominis gydymas yra chirurginis. Taikomi minimaliai invazyvūs endovaskuliniai gydymo metodai, tokie kaip endovaskulinè lazerio terapija, termoabliacija, cheminè skleroterapija, arba atvira operacija. Svarbiausias simptomų išnykimo veiksnys - visiška varikozinių venų sienelès obliteracija. Pooperacinị gijimą gerina komplikacijų išvengimas, kojos kompresinis gydymas.
\end{abstract}

\section{Ivadas}

Varikozinès venos (VV) - labai dažna patologija, kuri išsivysto net 30 proc. žmonių bent kartą per gyvenimą [1]. Ši patologija dažniau stebima vyresnio amžiaus žmonèms, moterims 2 kartus dažniau, negu vyrams [2]. Kliniškai VV klasifikuojama ị komplikuotą ir nekomplikuotą. Nekomplikuotoms varikozèms pakanka tik kosmetinio gydymo, ar paciento užtikrinimo, jog kol kas nèra žalingos. Komplikuotos varikozès pasireiškia klinikiniais simptomais, tokiais kaip kojų tinimas, sunkumas, silpnumas, vietinis skausmas, spontaninis kraujavimas, paviršinis tromboflebitas. Varikozinès venos gali sukelti edemą, skausmą, odos pakitimus, tokius kaip stazinis dermatitas ar opejjimas. Veninèms opoms sugyti gali prireikti daugiau nei 9 mènesių, o vienos studijos duomenimis, 66 proc. opų nesugijo per 5 metus. Visi šie simptomai trukdo normaliam kasdieniam funkcionalumui ir gyvenimo kokybei $[2,11]$.

Tyrimo tikslas - išnagrinèti dažniausiai taikomus venų varikozės diagnostikos ir gydymo metodus.

\section{Tyrimo medžiaga ir metodai}

Atlikta mokslinès literatūros apžvalga. Duomenys rinkti iš kompiuterinių bibliografinių medicininių duomenų bazių Science Direct ir PubMed. Paieška buvo vykdoma naudojant reikšminius žodžius: varicose veins [MeSH Terms], varicose veins diagnostics [MeSH Terms], varicose veins treatment [MeSH Terms]. Straipsnių atrankos kriterijai: prieinama viso teksto publikacija, tekstas parašytas anglų kalba. Analizei atrinkti 35 viso teksto straipsniai, kurių pavadinimas, santrauka ir reikšminiai žodžiai atitiko tyrimo tikslą.

\section{Tyrimo rezultatai}

Varikozinių venų rizikos veiksniai. Varikozinès venos yra išsišokusios, išsipūtusios ir vingiuotos, paviršinès dažniausiai būna apie $4 \mathrm{~mm}$ dydžio. Varikozinès venos yra dažniausia lètinio veninio nepakankamumo išraiška, pasitaikanti iki 25 proc. moteru ir 15 proc. vyru [3]. Rizikos veiksniai: moteriškoji lytis, vyresnis amžius, rasè, šeiminè anamnezé, něštumas, ilgas stovèjimas, nutukimas, kraujagyslinès malformacijos ir hormonų terapija. Maždaug 4 proc. moterų venų varikozę sukelia dubens venų refliuksas [4]. Nëštumas ir giliujų venų refliuksas susiję su VV pasikartojimu, nepaisant prieš tai taikyto gydymo [5]. Kiti požymiai, rodantys venų patologiją, yra apžiūrint matomas išsiplètęs smulkiųjų venų tinklas, - 1-3 mm diametro, plokščios, melsvai žalsvos, šiek tiek vingiuotos venos. Kitas požymis teleangiektazijos, arba voratinklinès venos, kurių spindis $1 \mathrm{~mm}$ ar mažiau, mèlynos - juodai violetinès - raudonos spalvos venos. Škotijoje atlikto tyrimo, kurio imtis buvo 1566 pacientai, amžius nuo 18 iki 64 metų, duomenys parodè, jog 80 proc. vyrų ir 85 
proc. moterų, kurie turèjo $\mathrm{VV}$, buvo ryškios teleangiektazijos arba voratinklinès venos [6].

Anatomija. Apibendrintai, apatinių galūnių venos skirstomos į 3 sistemas ( paviršines, giliąsias, perforuojančias), kurios tarpusavy susijungusios ị vieną bendrą tinklą ir suteka $i$ išorinę klubinę veną. Giliąsias venas dengia raumeninè fascija, paviršines - derma. Paviršinių venų aukštyje poodiniame tarpe yra poodinè vena (v. saphena), ìvertinama ultragarsu. Perforuojančios venos jungia paviršines ir giliąsias venas tarpusavy, kerta raumeninę fasciją.

Patogenezè. Varikozines venas sukelia susilpnëjusi veninè sienelè. Ligos etiologija gali būti pirminè ir antrinè. Pirminè - kai dèl idiopatinių priežasčių atsiranda struktūrinių ar funkcinių veninès sistemos defektų. Antrinę sukelia veninė obstrukcija, dažniausiai giliujų venų, arba giliujų venų nepakankamumas. Dažniausiai ši patologija kyla dèl venų vožtuvų disfunkcijos. Net 8 iš 10 pacientų venų varikozę sukelia pirminis venų vožtuvų nepakankamumas. Antrinis vožtuvų refliuksas dažniausiai susiformuoja po traumos arba trombozès. Igimtos anomalijos sudaro tik 2 proc. pacientų su šia patologija [7].

Antrinè lètinè venų liga vystosi greičiau, nei pirminè. Svarbus veiksnys yra veninè hipertenzija. Veninis spaudimas yra tiesiogiai proporcingas kraujo stulpelio spaudimui iš dešiniojo prieširdžio ị koją, atėmus spaudimą, sukeliamą dèl raumenų kontrakcijos. Stovint veninis spaudimas gali pasiekti $90 \mathrm{mmHg}$. Laikinai šis spaudimas didejja dèl raumenų darbo, tačiau greit sumažeja dèl venų vožtuvų nesandarumo. Vystantis šiai patologijai, koja tinsta, atsiranda edema, o po jos ir uždegiminè kaskada. Esant padidèjusiam veniniam spaudimui daugiau nei 90

1 lentelè. Venų varikozès išorinių požymių klasifikacija CEAP sistemoje $[9,10]$.

\begin{tabular}{|l|l|}
\hline $\begin{array}{l}\text { CEAP } \\
\text { kodas }\end{array}$ & \multicolumn{1}{|c|}{ Išoriniai požymiai } \\
\hline $\mathrm{C} 0$ & $\begin{array}{l}\text { Nėra išoriškai matomų, užčiuopiamų palpacijos metu } \\
\text { venų ligos požymių }\end{array}$ \\
\hline $\mathrm{C} 1$ & Teleangiektazijos ar voratinklinės venos \\
\hline $\mathrm{C} 2$ & Varikozinės venos \\
\hline $\mathrm{C} 2 \mathrm{r}$ & Pasikartojančios VV \\
\hline $\mathrm{C} 3$ & Edema \\
\hline $\mathrm{C} 4$ & $\begin{array}{l}\text { Pokyčiai odoje ir poodiniame sluoksnyje dėl lètinės } \\
\text { venų ligos }\end{array}$ \\
\hline $\mathrm{C} 4 \mathrm{a}$ & Pigmentacija ar egzema \\
\hline $\mathrm{C} 4 \mathrm{~b}$ & Lipodermatosklerozė ar blyškioji atrofija \\
\hline $\mathrm{C} 4 \mathrm{c}$ & Corona phlebectatica \\
\hline $\mathrm{C} 5$ & Sugijusi veninė opa \\
\hline $\mathrm{C} 6$ & Aktyvi veninė opa \\
\hline $\mathrm{C} 6 \mathrm{r}$ & Pasikartojanti aktyvi opa \\
\hline
\end{tabular}

mmHg, opų rizika padidèja beveik 100 procentų [6, 8].

Klinikinė išraiška. Klinikinè venų varikozès išraiška yra nuo kosmetinių bėdų iki rimtų simptomų, tokių kaip opos. 1994 metais Amerikoje sukurta tarptautinè lètinio venų nepakankamumo klasifikacija, žinoma kaip CEAP sistema (angl. Clinical-Etiology-Anatomy-Pathophysiology), aprépianti susirgimo kliniką, etiologiją, anatomiją (lokalizaciją) ir patofiziologiją. VV išorinių požymių klasifikacija CEAP sistemoje parodyta 1 lentelèje.

Kliniškai VV klasifikuojama ị komplikuotą ir nekomplikuotą. Nekomplikuotoms varikozèms pakanka kosmetinio gydymo, ar paciento užtikrinimo, jog jos kol kas nėra žalingos. Komplikuotos varikozès pasireiškia klinikiniais simptomais, tokiais kaip kojų sunkumas, tinimas, silpnumas, vietinis skausmas, spontaninis kraujavimas, paviršinis tromboflebitas. Varikozinès venos gali sukelti edemą, skausmą, odos pakitimus, tokius kaip stazinis dermatitas ar opejimas. Veninėms opoms sugyti gali prireikti daugiau nei 9 mėnesių, o vienos studijos duomenimis, 66 proc. opų nesugijo per 5 metus. Šie simptomai trukdo normaliam kasdieniam funkcionalumui ir gyvenimo kokybei $[2,11]$.

Fizinis tyrimas. Kojos išvaizdos pirminès apžiūros metu galima pamatyti patinimą (edemą), išsišokusias VV, cianozę, raudonį, hiperpigmentaciją, lipodermatosklerozę, opas. Siekiant ịvertinti veninị refliuksą (pacientui stovint), VV matomos išsipūtusios, išsišokusios, išsiplètusios $4 \mathrm{~mm}$ ar daugiau. Lipodermatosklerozė dažnai rodo vietinį lètinị uždegimą su odos ir poodinio audinio fibroze. Odos pokyčiai dažnai matomi ten, kur dažniausiai kojas dengia kojinè, vidinèje kulkšnies pusèje. Dèl stipraus lètinio veninio nepakankamumo gali būti stebima apskrita balkšva, nevaskuliarizuota atrofinès odos zona, apsupta kapiliarų ir kartais hiperpigmentacijos, vadinamos blyškiaja atrofija (Atrophie blanche) [12].

Fizinio tyrimo metu gali būti taikomi Trendelenburg ir Perthes testai, siekiant diferencijuoti paviršinių ar giliujų venų nepakankamumą. Trendelenburg testo metu koja būna pakelta su užveržtu turniketu virš kelio, blokuojant paviršines venas, kurios greitai prisipildytų pacientui atsistojus dèl giliujų venų nepakankamumo. Jeigu pacientui atsistojus venos prisipildo vẻliau nei per 20 sekundžių, priežastis pirminè, giliujų venų vožtuvų nepakankamumo nẻra. Perthes testo metu išsiaiškinama, ar VV užsipildo dèl prastai veikiančių perforatorinių venų vožtuvų [13].

Vaizdo diagnostikos metodai. Auksinis standartas diagnozuojant VV yra duplex ultragarsinis tyrimas spalviniu režimu. Tyrimas atliekamas pacientui stovint arba atvirkštinejje Trendelinburg pozicijoje, taikomas aptikti ūmią arba lètinę trombozę, potrombozinius pokyčius, susilpnèjusị veninio kraujo pratekamumą ir giliųjų venų nepakankamumą. 
Grịžtamosios srovès refliuksas yra patologinis radinys, jei trunka ilgiau nei 0,5 sekundès. Duplex ultrasonografijos metodu galima sèkmingai aptikti ir ịvertinti poodinès venos refliuksą ir perforuojančiujų venų nepakankamumą, tačiau šis tyrimas neinformatyvus vertinant klubines bei tuščiąsias venas [14]. Rečiau taikomas tyrimo metodas yra pletismografija. Jis gali būti naudojamas įvertinti venų obstrukcijos ar refliukso požymius stambiosiose venose virš kelio., Kai siekiama išsiaiškinti paviršinių venų nepakankamumą, dažniausiai atliekama fotopletismografija be turniketo. Venos užsipildymo laikas mažesnis nei 20 sekundžiu be turniketo ir daugiau nei 20 sekundžių su turniketu rodo v.saphena magna nepakankamumą. [14,15].

Tinkamos gydymo taktikos pasirinkimas. Varikoziniu venų gydymas gali būti konservatyvus ir invazinis. Konservatyvus varikozinių venų ir lètinio venų nepakankamumo gydymas apima gyvenimo būdo modifikacijas, kompresinę terapiją ir farmakoterapiją. Invazyvios technikos taikymas priklauso nuo venų būklès, dydžio ir esamų komplikacijų. Dažniausiai termodažnuminė abliacija (TDA) taikoma didžiosioms poodinèms varikozinėms venoms, kurių sutrikusi funkcija, siekiant atpalaiduoti distaliau esančias varikozes. Siekiant optimalaus terapinio ir estetinio efekto, daugeliui pacientų prireikia ir kombinuotų gydymo būdų. Didžiajai poodinei kojos venai dažniau naudojama endoveninè lazerio terapija (ELT) ar radiodažnuminé abliacija (RDA). Didžiosios poodinès venos, kurių skersmuo yra nuo 3 iki $12 \mathrm{~mm}$, yra tinkamiausios radiodažnuminei abliacijai. ELT yra tinkamesnis būdas, jei venos skersmuo didesnis nei 3 mm. Mažiau invazyvi technika - skleroterapija klijais didžiujjų poodinių venų gydymui tinka, jei venos spindis mažesnis nei $1 \mathrm{~cm}$, tačiau gali būti taikoma ir gydant didesnio spindžio venas[16]. Jei didžiosios poodinès venos spindis didesnis nei $12 \mathrm{~mm}$, taikomas operacinis gydymas [17]. Ne mažiau nei skersmuo svarbus ir venos vingiuotumas. Tiesių segmentų gydymui tinkamiausia ELT ir RDA, kai tiesios didžiosios poodinès venos atkarpos ilgis yra bent $15-20 \mathrm{~cm}$ nuo safenofemoralinès jungties. Tyrimas, kuriame dalyvavo 577 pacientai, turintys poodinès venos refliuksą, parode, kad 55 proc. atvejų buvo tinkami ELT ir RDA ir 57 proc. - skleroterapijai. Akcentuojant kruopštų šio tyrimo pacientų atrankos poreikį, tik mažiau nei 41 proc. galūnių buvo tinkamos visoms procedūroms [17]. Tyrime vertinant pasikartojančią venų varikozę, mažiau nei 40 proc. galūnių buvo tinkamos ELT ir RDA, o skleroterapijai klijais buvo tinkami 58 proc. atvejų. Dél nudegimų rizikos, paviršinis veninis intakas nèra tinkamas kateterinei terminei abliacijai. Optimaliausias terapinis efektas pasiekiamas taikant kombinuotas metodikas [17].

\section{Konservatyviojo gydymo metodai}

Gyvenimo būdo korekcija. Pernelyg ilgas stovèjimas ar sėdejjimas gali pasunkinti venų varikozès simptomus. Pacientams rekomeduotina pakelti kojas virš širdies lygio, numesti svorio bei sportuoti, kad sumažintų tinimą ir pagerintų blauzdų raumenų funkciją [18]. Vidutinio intensyvumo apatinių galūnių mankšta po venų varikozès operacijos pagerina mikrokraujagyslinę endotelinę vazodilatacinę funkciją [19].

Kompresijos taikymas. Išoriškai taikoma kompresija yra viena geriausių ligos prevencijos ir palaikomoji priemonè po intervencinio gydymo. Tiek elastinès kompresinès kojinès, tiek elastiniai bintai efektyviai mažina kojų skausmus ir tinimą, padeda pristabdyti VV progresavimą iki lètinio veninio nepakankamumo ir venų sukeliamų opų [18]. Vieno randomizuoto tyrimo duomenimis, 206 pacientams (amžiaus vidurkis 49,7 m., 49 proc.moterų ir 51 proc. vyrų), kuriems buvo taikyta ELT, viena grupe devejjo kompresines kojines, o kita nenaudojo jokių kompresinių priemonių. Rezultatai skelbia, jog kojinių dèvejjimas sumažino pooperacini skausmą, kojų tinimą ir prisidejjo prie greitesnio fizinių kojos funkcijų atkūrimo [20].

\section{Intervencinio gydymo metodai}

Endoveninė lazerio terapija. Procedūros pradžioje taikoma vietinè infiltracinè nejautra iki venos guolio, vèliau naudojant UG endoveniškai ịterpiamas kateteris kelio aukštyje ir daviklis vedamas per safenofemoralinę jungti, dažniausiai iki norimos didžiosios poodinès venos vietos. Lazerio tiesioginiu (karščiu) ir netiesioginiu (karštais garais) poveikiu sukeliamas varikozinès venos sienelès sunaikinimas, venos susitraukimas ir fibrozė $[11,21,18]$. Kontraindikacija: labai vingiuotos ar labai smulkios venos, kuriu skersmuo $\geq 12 \mathrm{~mm}$, o atstumas nuo odos $\leq 1 \mathrm{~cm}$, arba lokalizuota blauzdoje, arba venos spindyje laisvas trombas [22]. Metaanalizès duomenimis, venos obliteracijos dažnis po 3 mèn. 92,9\% (95\% PI, 90,2-94,8); po 1 metu 93,3\% (95\% PI, 91,1-95,0); po 3 metu 94,5\% (95\% PI, 87,2-97,7\%); po 5 metų 95,4\% (95\% PI, 79,7-99,1) [23]. Kitos studijos parodè labai panašius rezultatus [24,25]. Keletas studijų parodè geresnius ELT rezultatus, lyginant su chirurgine intervencija ir kitomis endoveninèmis gydymo taktikomis [24].

Dažniausios komplikacijos - vidutinio stiprumo skausmas 50 proc., edema, eritema, echimozès 40 proc., hematoma 23 proc., hipo/hiperpigmentacija, paviršinis tromboflebitas 12 proc., giliujų venų trombozè 7 proc., praeinanti kojos parestezija 10 procentų $[21,26]$.

Radiodažnuminė abliacija. Procedūros pradžioje taikoma bendriné arba vietinè infiltraciné nejautra iki venos guolio, vèliau, naudojant UG, kelio aukštyje endoveniškai itterpiamas kateteris, kol pasiekiama safenofemoralinè jungtis, ir vedamas iki norimos didžiosios poodinès venos vietos. 
Venos sienelè veikiama radijo bangomis tarp endo bipolinių elektrodų, kurie sukelia staigų venos susitraukimą ir okliuziją. Po šios procedūros dažniausiai taikomos kompresinès priemonès [11,18,21]. Kontraindikacijos panašios ị ELT [22].

Metaanalizès duomenimis, venos obliteracijos dažnis po 3 mèn. 88,8\% (95\% PI, 83,6-92,5); po 1 metų 87,7\% (95\% PI, 83,1-91,2); po 3 metų 84,2\% (95\% PI, 75,2-90,4); po 5 metu 79,9\% (95\% PI, 59,5-91,5) [23]. Simptominis pagerèjimas pastebètas nuo 85 iki 94 proc. pacientų, esant palankiai venų anatomijai $[26,27]$. Dažniausios komplikacijos $(n=286)$ : odos nudeginimas 2,1 proc., infekcija, hematoma 5 proc., hipo/hiperpigmentacija, paviršinis tromboflebitas 2,1 proc., giliujų venų trombozè 16 proc., praeinanti kojos parestezija 15 proc., nemirtina plaučių embolija 1 procentas [26,27].

Cheminè skleroterapija. Cheminis sklerozantas (polidocanol, natrio morrhuate, ar natrio tetradecyl sulfate [STDS]) sumaišomas su anglies dioksidu $\left(\mathrm{CO}_{2}\right)$ ir oru siekiant išgauti putas (koncentracija 1-3\%; tūris 6-8 ml)[28]. $\mathrm{CO}_{2}$ sumažina mikroburbuliukų susidarymo riziką ir embolizaciją oru, nes jis geriau tirpsta kraujyje ir vandenyje negu aplinkoje esančiame azote [29]. Toliau taikoma UG kontrolè, siekiant identifikuoti labiausiai paviršiuje esantị VV segmentą. I segmentą suleidžiama sklerozuojančios medžiagos, užspaudžiama safenofemoralinè jungtis, siekiant išvengti mikroburbuliukų keliamo embolizacijos pavojaus. Koja pakeliama $45^{\circ} \mathrm{kampu}$ ir masažuojama distaliai, kad medžiaga užpildytų norimą sienelès spindị. Po procedūros taikomi kompresijos bintai (kojinès). Pati skleruozuojanti medžiaga keičia kraują venos spindyje ir maždaug per 1-2 savaites sukelia sklerozę ir obliteraciją [28]. Dažniausios komplikacijos: silpnas - vidutinis skausmas, hiperpigmentacija (dažniausiai išnyksta po 6-12 mèn.), paviršinis tromboflebitas 5 proc., giliųų venų trombozè (pakinklio, blauzdos srities), praeinantys neurologiniai epizodai (galvos skausmas, svaigumas) 1 proc., miokardo infarktas, galvos smegenų insultas [30-32]. Metaanalizès duomenimis, venos obliteracijos dažnis po 3 mèn. $82,1 \%$ (95\% PI, 72,5-88,9); po 1 metu 80,9\% (95\% PI, 71,8-87,6); po 3 metų $77,4 \%$ (95\% PI, 68,7-84,3); po 5 metų $73,5 \%$ (95\% PI, 62,8-82,1) [23]. Kontraindikacijos: staigi giliujų venų trombozè, ūmios infekcijos, alergija sklerozantinei medžiagai, nèštumas, žindymas krūtimi [28].

\section{Chirurginis gydymas}

Atvira chirurginė operacija. Pirmoji atvira VV operacija atlikta 1844 metais [33]. Operacija atliekama bendrinèje nejautroje. Procedūros metu daromas pjūvis kirkšnies srityje dèl prièjimo prie didžiosios poodinès venos, naudojama kieta lanksti viela, kurios laisvas galas vedamas per visą venos ilgi, kol pasiekia blauzdos viršų ir tuomet pašalinama [5,34]. Šios operacijos metu pašalinama didžioji arba mažoji poodine kojos vena su savo šakomis (visas kamienas) nuo kulkš- nies iki safenofemoralinės jungties arba iki safenopoplitinès jungties [22]. Ši procedūra tinka ir paviršinio tromboflebito šalinimui. Identifikuoti anatominę varikozinès venos lokaciją tiek prieš, tiek po, puikiai tinka UG tyrimas [22]. Dažniausios komplikacijos: skausmas, kraujavimas ir hematoma 24 proc., infekcija 2-15 proc., nervo pažeidimas 25 proc., paviršinis tromboflebitas, giliujų venų trombozė ar plaučių embolija 2 procentai $[21,35]$. Metaanalizès duomenimis, venos obliteracijos dažnis po 3 mèn. 80,4\% (95\% PI, 72,3-86,5); po 1 metų 79,7\% (95\% PI, 71,8-85,8); po 3 metų 77,8\% (95\% PI, 70,0-84,0); po 5 metų 75,7\% (95\% PI, 67,9-82,1) [21]. Kontraindikacijos: giliujų venų trombozè, Klippel-Trénaunay sindromas, periferinè arterijų liga ar neuropatija, dèl kurių galètų blogiau gyti žaizda ir padidèti infekcijos rizika $[11,18,35]$.

\section{Išvados}

1. Venų varikozės diagnozei patvirtinti auksinis standartas yra Duplex ultragarsinis tyrimas, papildytas paciento kojų apžiūra, apčiuopa, CEAP klasifikacija, diferencinès diagnostikos testais (Trendelenburg ir Perthes).

2. Venų varikozès gydymui vis dar plačiai naudojami ne tik endovaskulinio gydymo metodai (cheminè skleroterapija, radiodažnuminè abliacija, endovaskulinè lazerio terapija), bet ir atviras operacijos tipas. Geriausi venos obliteracijos rezultatai atsižvelgiant ị būklès stebejjimą po 3 mènesių, 1 , 3 ir 5 metų pagal gydymo būdą buvo endovaskulinès lazerio terapijos, radijo dažnuminès abliacijos. Prastesni venos obliteracijos rezultatai buvo cheminès skleroterapijos ir atviros operacijos būdu gydytų pacientų.

3. Po operacijos rekomenduojama kompresinè profilaktika kojinėmis ar bintais, siekiant mažesnio pooperacinio skausmo, tinimo ir greitesnio funkcijos atsikūrimo.

\section{Literatūra}

1. Hamdan A. Management of Varicose Veins and Venous Insufficiency. JAMA 2012;308(24):2612.

https://doi.org/10.1001/jama.2012.111352

2. Bergan JJ, Schmid-Schönbein GW, Smith PDC, Nicolaides AN, Boisseau MR, Eklof B. Chronic Venous Disease. N Engl J Med 2006;355(5):488-98.

https://doi.org/10.1056/NEJMra055289

3. Callam MJ. Epidemiology of varicose veins. Br J Surg 2005;81(2):167-73.

https://doi.org/10.1002/bjs.1800810204

4. Marsh P, Holdstock J, Harrison C, Smith C, Price BA, Whiteley MS. Pelvic vein reflux in female patients with varicose veins: comparison of incidence between a specialist private vein clinic and the vascular department of a National Health Service district general hospital. Phlebol J Venous Dis 2009;24(3):108-13. 
https://doi.org/10.1258/phleb.2008.008041

5. Miyazaki K, Nishibe T, Sata F, Murashita T, Kudo FA, Miyazaki YJ, et al. Long-term results of treatments for varicose veins due to greater saphenous vein insufficiency. Int Angiol 2005;24(3):282-6.

http:/www.ncbi.nlm.nih.gov/pubmed/16158040

6. Evans CJ, Fowkes FG, Ruckley C V, Lee AJ. Prevalence of varicose veins and chronic venous insufficiency in men and women in the general population: Edinburgh Vein Study. J Epidemiol Community Heal 1999;53(3):149-53.

https://doi.org/10.1136/jech.53.3.149

7. Youn YJ, Lee J. Chronic venous insufficiency and varicose veins of the lower extremities. Korean J Intern Med 2019;34(2):26983.

https://doi.org/10.3904/kjim.2018.230

8. Raffetto J, Khalil R. Matrix Metalloproteinases in Venous Tissue Remodeling and Varicose Vein Formation. Curr Vasc Pharmacol 2008;6(3):158-72.

https://doi.org/10.2174/157016108784911957

9. Raju S, Neglén P. Chronic Venous Insufficiency and Varicose Veins. N Engl J Med 2009;360(22):2319-27. http://www.nejm. org/doi/abs/10.1056/NEJMcp0802444

https://doi.org/10.1056/NEJMcp0802444

10. Rutherford RB, Padberg FT, Comerota AJ, Kistner RL, Meissner MH, Moneta GL. Venous severity scoring: An adjunct to venous outcome assessment. J Vasc Surg 2000;31(6):1307-12. https://doi.org/10.1067/mva.2000.107094

11. Bartholomew JR, King T, Sahgal A, Vidimos AT. Varicose veins: newer, better treatments available. Cleve Clin J Med 2005;72(4):312-4.

https://doi.org/10.3949/ccjm.72.4.312

12. Nael R, Rathbun S. Treatment of varicose veins. Curr Treat Options Cardiovasc Med 2009;11(2):91-103.

https://doi.org/10.1007/s11936-009-0010-Z

13. Kim J, Richards S, Kent PJ. Clinical examination of varicose veins--a validation study. Ann R Coll Surg Engl 2000;82(3):171-5.

http://www.ncbi.nlm.nih.gov/pubmed/10858678

14. Tolu I, Durmaz MS. Frequency and Significance of Perforating Venous Insufficiency in Patients with Chronic Venous Insufficiency of Lower Extremity. Eurasian J Med 2018;50(2). https://doi.org/10.5152/eurasianjmed.2018.18338

15. Nybo J, Nybo M, Hvas A-M. [Diagnostic work-up and treatment of superficial vein thrombosis]. Ugeskr Laeger 2018;180(33). http://www.ncbi.nlm.nih.gov/pubmed/30084349

16. Goode SD, Kuhan G, Altaf N, Simpson R, Beech A, Richards T, et al. Suitability of Varicose Veins for Endovenous Treatments. Cardiovasc Intervent Radiol 2009;32(5):988-91. https://doi.org/10.1007/s00270-009-9616-5

17. Luebke T, Gawenda M, Heckenkamp J, Brunkwall J. MetaAnalysis of Endovenous Radiofrequency Obliteration of the
Great Saphenous Vein in Primary Varicosis. J Endovasc Ther 2008;15(2):213-23.

https://doi.org/10.1583/07-2287.1

18. Rathbun SW, Kirkpatrick AC. Treatment of chronic venous insufficiency. Curr Treat Options Cardiovasc Med 2007;9(2):115-26. https://doi.org/10.1007/s11936-007-0005-6

19. Klonizakis M, Tew G, Michaels J, Saxton J. Exercise training improves cutaneous microvascular endothelial function in postsurgical varicose vein patients. Microvasc Res 2009;78(1):6770.

https://doi.org/10.1016/j.mvr.2009.03.002

20. Bootun R, Belramman A, Bolton-Saghdaoui L, Lane TRA, Riga C, Davies AH. Randomized Controlled Trial of Compression After Endovenous Thermal Ablation of Varicose Veins (COMETA Trial). Ann Surg 2021;273(2):232-9. https://doi.org/10.1097/SLA.0000000000003626

21. Beale RJ, Gough MJ. Treatment Options for Primary Varicose Veins-A Review. Eur J Vasc Endovasc Surg 2005;30(1):83-95. https://doi.org/10.1016/j.ejvs.2005.02.023

22. Sadick NS. Advances in the Treatment of Varicose Veins: Ambulatory Phlebectomy, Foam Sclerotherapy, Endovascular Laser, and Radiofrequency Closure. Dermatol Clin 2005;23(3):443-55.

https://doi.org/10.1016/j.det.2005.03.005

23. van den Bos R, Arends L, Kockaert M, Neumann M, Nijsten T. Endovenous therapies of lower extremity varicosities: A meta-analysis. J Vasc Surg 2009;49(1):230-9.

https://doi.org/10.1016/j.jvs.2008.06.030

24. Luebke T, Brunkwall J. Systematic review and meta-analysis of endovenous radiofrequency obliteration, endovenous laser therapy, and foam sclerotherapy for primary varicosis. J Cardiovasc Surg (Torino) 2008;49(2):213-33.

https://doi.org/10.1583/07-2287.1

25. Puggioni A, Kalra M, Carmo M, Mozes G, Gloviczki P. Endovenous laser therapy and radiofrequency ablation of the great saphenous vein: Analysis of early efficacy and complications. J Vasc Surg 2005;42(3):488-93.

https://doi.org/10.1016/j.jvs.2005.05.014

26. Pannier F, Rabe E. Endovenous laser therapy and radiofrequency ablation of saphenous varicose veins. J Cardiovasc Surg (Torino) 2006;47(1):3-8. http://www.ncbi.nlm.nih.gov/ pubmed/16434940

27. Merchant RF, Pichot O. Long-term outcomes of endovenous radiofrequency obliteration of saphenous reflux as a treatment for superficial venous insufficiency. J Vasc Surg 2005;42(3):502-10

https://doi.org/10.1016/j.jvs.2005.05.007

28. Breu F-X, Guggenbichler S. European Consensus Meeting on Foam Sclerotherapy, April, 4-6, 2003, Tegernsee, Germany. Dermatologic Surg 2004;30(5):709-17.

https://doi.org/10.1111/j.1524-4725.2004.30209.x 
29. Smith PC. Foam and liquid sclerotherapy for varicose veins. Phlebol J Venous Dis 2009;24(1_suppl):62-72. https://doi.org/10.1258/phleb.2009.09s007

30. Guex J-J, Allaert F-A, Gillet J-L, Chleir F. Immediate and Midterm Complications of Sclerotherapy: Report of a Prospective Multicenter Registry of 12,173 Sclerotherapy Sessions. Dermatologic Surg 2006;31(2):123-8. https://doi.org/10.1111/j.1524-4725.2005.31030

31. Forlee MV, Grouden M, Moore DJ, Shanik G. Stroke after varicose vein foam injection sclerotherapy. J Vasc Surg 2006;43(1):162-4. https://doi.org/10.1016/j.jvs.2005.09.032

32. Bush RG, Derrick M, Manjoney D. Major neurological events following foam sclerotherapy. Phlebol J Venous Dis 2008;23(4):189-92. https://doi.org/10.1258/phleb.2007.007073

33. Yao JST. Presidential address: Venous disorders-Reflections of the past three decades. J Vasc Surg 1997;26(5):727-35. https://doi.org/10.1016/S0741-5214(97)70083-1

34. Belcaro G, Cesarone MR, di Renzo A, Brandolini R, Coen L, Acerbi G, et al. Foam-Sclerotherapy, Surgery, Sclerotherapy, and Combined Treatment for Varicose Veins: A 10-Year, Prospective, Randomized, Controlled, Trial (VEDICO Trial). Angiology 2003;54(3):307-15. https://doi.org/10.1177/000331970305400306

35. Rigby KA, Palfreyman SS, Beverley C, Michaels JA. Surgery versus sclerotherapy for the treatment of varicose veins. Cochrane Database Syst Rev 2004.

https://doi.org/10.1002/14651858.CD004980

\section{VARICOSE VEINS: DIAGNOSTICS AND TREATMENT \\ J. Vitkus, I. Floreskul, D. Misevičius}

Keywords: varicose veins, diagnostics, treatment. Summary

Varicose veins are dilated, buldging and often palpable subcutaneous veins with reversed blood flow. They are most commonly found in the legs. Visible varicose veins in the lower limbs are estimated to affect at least a third of the population. The aim of this study is to analyse varicose veins (VV) diagnostic and treatment. The main risk factors are female sex, age, ethnicity, family history, pregnancy, hormonal therapy and vascular malformations. The symptoms are specific- oedema, buldging and plump varicosed veins, pain in the legs during/ or post physical activity, skin cyanosis, pruritus, hyper/hypo- pigmentation, lypodermatosclerosis, ulcerations. The golden diagnostic standart is duplex ultrasonography with clinical examination. Symptomatic VV treatment is surgical. Emerging endovenous therapies, including endovenous laser therapy, radiofrequency ablation, and endovenous foam sclerotherapy, have shown similar efficacy in the treatment of VV's compared with more invasive surgical procedures. The goal of the treatment is a total obliteration of compromised venus vall.

Correspondence to: jvitkus007@gmail.com

Gauta 2021-05-25 